\title{
Pengembangan Buku Ajar Teori Graf untuk Meningkatkan Kemampuan Representasi Matematis Siswa pada Mata Kuliah Matematika Diskrit
}

\author{
Farida Daniel ${ }^{1}$, Prida N. L. Taneo ${ }^{2}$ \\ 1,2Program Studi Pendidikan Matematika, STKIP Soe \\ E-mail: faridaniel46@ gmail.com ${ }^{1}$,nemserayah.19@ gmail.com²
}

\begin{abstract}
Abstrak
Penelitian ini bertujuan untuk mengembangkan buku ajar teori graf yang valid, praktis dan efektif dalam meningkatkan kemampuan representasi matematis mahasiswadalam pembelajaran teori graf pada matakuliah matematika diskrit.Metode yang digunakan adalah penelitian dan pengembangan dengan desain pengembangan mengikuti model Plomp yang terdiri dari lima tahapan berupa (1) investigasi awal, (2) desain, (3) realisasi/konstruksi, (4) tes, evaluasi dan revisi, (5) implementasi. Subjek pada penelitian ini adalah mahasiswa yang mengambil mata kuliah matematika diskrit, tahun akademik 2018/2019 program studi pendidikan Matematika STKIP Soe sebanyak dua kelas.Teknik pengumpulan data penelitian berupa observasi, tes dan angket.Produk berupa buku ajar teori graf yang dikembangkan diuji validitasnya berdasarkan hasil penilaian dari tim ahli sebagai validator. Kepraktisan produk diuji menggunakan analisis angketrespon mahasiswa dan dosen. Uji keefektifan buku ajar dalam meningkatkan kemampuan representasi matematis dilakukan melalui penelitian quasi eksperimen dengan teknik analisis menggunakan uji t sampel independen dan skor gain normalisasi. Hasil penelitian menunjukkan bahwa buku ajar teori graf yang dikembangkan valid, praktis dan efektif dalam meningkatkan kemampuan representasi matematis mahasiswa.
\end{abstract}

Kata Kunci: buku ajar, matematika diskrit, representasi matematis, teori graf.

\section{Development of Graph Theory Textbooks to Improve Students' Mathematical Representation Ability in Discrete Mathematics Subjects}

\begin{abstract}
This research aims to develop a graph theory textbook that is valid, practical and effective in improving students' mathematical representation abilities in learning graph theory in discrete mathematics courses. The method used is research and development with the Plomp model development design which consists of five stages in the form of (1) initial investigation, (2) design, (3) realization/construction, (4) tests, evaluations and revisions, (5) implementation. The subjects in this study were students who took discrete mathematics subjects, academic year 2018/2019 Mathematics education program STKIP Soe as many as two classes. Research data collection techniques in the form of observation, tests and questionnaires. The product in the form of a graph theory textbook that was developed was tested for validity based on the results of the assessment of the expert team as a validator. The practicality of the product was tested using questionnaire analysis of student and lecturer responses. Test the effectiveness of textbooks in improving the ability of mathematical representation is done through quasi-experimental research with analysis techniques using independent sample $t$ test and normalized gain score. The results showed that the graph theory textbooks developed were valid, practical and effective in improving students' mathematical representation abilities.
\end{abstract}

Keywords:discrete mathematics, mathematical representation, textbooks.

\section{PENDAHULUAN}

Matematika merupakan salah satu cabang ilmu yang mendasari perkembangan teknologi modern, mempunyai peran penting dalam berbagai disiplin dan memajukan daya pikir manusia untuk menguasai dan mencipta teknologi dimasa depan (Permendiknas no 22 tahun 2006). Mata pelajaran matematika perlu diberikan kepada semua siswa mulai dari tingkat sekolah dasar untuk membekali 
siswa dengan kemampuan berpikir logis, analitis, sistematis, kritis dan kreatif serta kemampuan bekerja sama(Amin dkk, 2016).

National Council of Teachers of Mathematics/NCTM(2000) merumuskan kemampuan dasar matematika meliputi kemampuan pemecahan masalah (problem solving), komunikasi (communication), koneksi (connection), penalaran (reasoning) dan representasi (representation). Representasi merupakan ungkapan dari gagasan-gagasan atau ide-ide matematika yang ditampilkan siswa dalam upayanya untuk mencari suatu solusi dari masalah yang sedang dihadapinya (Syafri, 2017).

Kemampuan representasi matematis merupakan kemampuan mengungkapkan gagasan atau ide matematika yang ditampilkan siswa dalam upayanya untuk mencari suatu solusi dari masalah yang sedang dihadapinya (NCTM, 2000). Indikator kemampuan representasi matematis yang digunakan pada penelitian ini merujuk dari Sinaga (2016) yaitu: 1) Representasi visual: (a) menggunakan diagram, tabel atau grafik untuk menyelesaikan atau menyimpulkan masalah (b) membuat gambar untuk memperjelas masalah dan memfasilitasi penyelesaiannya; (2) Representasi verbal: (a) menuliskan langkah-langkah penyelesaian masalah menggunakan kata-kata (b) menyimpulkan atau menjawab soal menggunakan kata-kata dan (3) Representasi simbolik: (a) membuat model matematis dari masalah yang diberikan (b) menyelesaikan masalah dengan melibatkan ekspresi matematis.

Berdasarkan hasil observasi yang dilakukan pada mahasiswa program studi pendidikan matematika STKIP Soe yang mengambil mata kuliah matematika diskrit semester genap tahun akademik 2017/2018 diperoleh bahwa dalam proses pembelajaran mahasiswa mengalami kesulitan dalam menyelesaikan permasalahan teori graf. Hal ini ditandai dengan masih banyak mahasiswa yang keliru dalam membuat model graf yang bersesuaian dengan matriks maupun keterangan lain yang diberikan. Dalam pembelajaran aplikasi pewarnaan grafpun mahasiswa juga kurang mampu merepresentasikan permasalahan kontekstual ke dalam model graf yang tepat sehingga kesimpulan terkait penyelesaian permasalahan tersebutmasih salah. Hal ini menyebabkan hasil belajar mahasiswa pada mata kuliah matematika diskrit rendah.

Hasil analisis terhadap kesulitan mahasiswa dalam merepresentasikan ide mereka dalam penyelesaian masalah menunjukkan bahwa mahasiswa kurang menguasai materi teori graf. Hasil wawancara terhadap mahasiswa juga diperoleh informasi bahwa salah satu penyebab kurangnya penguasaan materi teori graf dalam matakuliah matematika diskrit adalah kurangnya bahan bacaan berbahasa indonesiasebagai pegangan mahasiswa dalam perkuliahan. Bahan ajar yang dipakai dosen hanya berupa e-book dalam bahasa inggris dan juga bahan ajar non cetak berupa file power point. Buku-buku yang ada di perpustakaan kampus yang berkaitan dengan teori graf dan matematika diskrit jumlahnya juga terbatas.Keterbatasan bahan bacaan mengakibatkan penguasaan materi dan kemampuan representasi matematis mahasiswa rendah.Agar mahasiswa mengalami kemudahan dalam memahami berbagai materi dalam perkuliahan maka perlu disusun dan dikembangkan buku ajar yang dapat mengarahkan dan merangsang proses berpikir mahasiswa dalam memaksimalkan kemampuan representasi matematis mahasiswa.

Kegiatan yang dapat dilakukan oleh siswa dalam pembelajaran untuk mengembangkan kemampuan representasi adalah ketika siswa dihadapkan pada suatu situasi masalah matematika (Sabirin, 2017).Pemilihan dan penggunaan buku ajar yang tepat dalam proses perkuliahan merupakan faktor yang sangat penting untuk mengembangkan kemampuan representasi matematis mahasiswa. Buku ajar merupakan sebuah karya tulis yang berbentuk buku dalam bidang tertentu, yang merupakan buku standar yang digunakan guru dan siswa dalam proses belajar mengajar untuk maksud-maksud dan tujuan instruksional yang dilengkapi dengan sarana-sarana pengajaran yang serasi dan mudah dipahami oleh pemakainya di sekolah-sekolah dan perguruan tinggi sehingga dapat menunjang program pengajaran (Mudlofir, 2011). Hal ini menunjukkan bahwa buku ajar merupakan bagian yang penting dalam pembelajaran karena dapat digunakan sebagai sumber belajar baik bagi dosen maupun mahasiswa.Oleh karena itu, perlu mendesain buku ajar sebagai salah satu sumber belajar bagi mahasiswa.Buku ajar teori graf yang akan dikembangkan memuat materi defenisi dan konsep fundamental graf, pohon dan konektivitas, graf planar, pewarnaan graf dan graf berarah. Penggunaan modul sebagai bahan ajar membantu dosen dalam menyampaikan materi perkuliahan sehingga pencapaian kompetensi di setiap materi oleh mahasiswa dapat dilakukan dengan baik (Fitria, Arnawa 
dan Lufri, 2014). Bahan ajar dapat berpengaruh terhadap kemampuan representasi matematis matematika siswa, sebagaimana hasil penelitian Abdullah (2012) yang menyimpulkan bahwa pengembangan bahan ajar dan perangkat pembelajaran dapat digunakan dalam meningkatkan kemampuan pemahaman dan representasi matematik siswa melalui pembelajaran kontekstual yang terintegrasi dengan soft skill.

Penelitian ini bertujuan untuk mengembangkan buku ajar teori graf untuk meningkatkan kemampuan representasi matematis mahasiswa.Penelitian ini melihat kevalidan, kepraktisan dan keefektifan buku ajar teori graf terhadap peningkatan kemampuan representasi matematis mahasiswa pada matakuliah matematika diskrit.

\section{METODE}

Metode yang digunakan dalam penelitian ini adalah penelitian dan pengembangan (research and development). Desain penelitian dan pengembangan dalam perancangan buku ajar mengikuti pengembangan yang dikemukakan oleh Plomp yangterdiri dari lima tahapan yaitu (1) tahap investigasi awal (prelimenaryinvestigation); (2) tahap desain (design); (3) tahap realisasi/konstruksi (realization/construction); (4) tahap tes, evaluasi, dan revisi (test, evaluation, revision); dan (5) tahap implementasi (implementation).

Penelitian ini dilakukan di STKIP Soe pada semester genap tahun akademik 2018/2019.Subjek pada penelitian ini adalah mahasiswa program studi pendidikan matematika STKIP Soe yang mengambil mata kuliah matematika diskrit yang terdiri dari kelas eksperimen sebanyak 20 orang dan kelas kontrol sebanyak 23 orang yang ditentukan menggunakan teknik simple random sampling.

Buku ajar yang dikembangkan diuji validitasnya terlebih dahulu oleh tim ahli yang terdiri dari 2 validator, setelah dinyatakan valid diuji kepraktisan dan keefektifannya. Uji kepraktisan buku ajar yang dikembangkan ditentukan melalui respon mahasiswa dan teman sejawat (dosen) terhadap buku ajar yang dikembangkan dan proses pembelajaran (perkuliahan). Uji keefektifan buku ajar dalam meningkatkan kemampuan representasi matematis dilakukan melalui penelitian quasi eksperimenyang didesain dalam bentuk nonequivalent control grup design.Desain pada uji keefektifan melibatkan dua kelas sampel, yaitu kelas eksperimen (diajarkan menggunakan buku ajar teori graf) dan kelas kontrol (tidak diajarkan menggunakan buku tersebut).Pre-test diberikan kepada kelas eksperimen dan kelas kontrol untuk mengetahui kemampuan representasi matematis awal mahasiswa.Kelas eksperimen dikenai perlakuan/treatment yakni pembelajaran dilaksanakan dengan menerapkan buku ajar yang didesain.Pada akhir pembelajaran, dilaksanakan post-test bagi mahasiswa pada kelas eksperimen dan kelas kontrol untuk mengetahui kemampuan representasi matematis akhir mahasiswa.

Instrumen dan teknik pengumpulan data yang digunakan berupa: (1) observasi, digunakan untuk mengetahui proses belajar mata kuliah matematika diskrit materi teori graf; (2) tes, digunakan untuk mengumpulkan data mengenai kemampuan representasi matematis mahasiswa; (3) angket, digunakan untuk mengukur kepraktisan buku ajar yang dikembangkan berupa respon mahasiswa dan teman sejawat (dosen).Produk buku ajar yang dikembangkan dalam penelitian ini diuji validitasnya oleh dua validator dengan mengambil rata-ratanya.Kepraktisan buku ajar yang dikembangkan diuji menggunakan angket respon mahasiswa dan teman sejawat (dosen). Teknik analisis untuk uji keefektifan buku ajar menggunakan uji $t$ sampel independen dan perhitungan skor gain normalisasi untuk mengetahui kategori peningkatan kemampuan representasi matematis mahasiswa pada kelas eksperimen.

\section{HASIL DAN PEMBAHASAN}

Desain penelitian dan pengembangan dalam perancangan buku ajar teori graf mengikutitahapan pengembangan yang dikemukakan oleh Plomp yangterdiri darilima tahapan yaitu (1) tahap investigasi awal (prelimenaryinvestigation); (2) tahap desain (design); (3) tahap realisasi/konstruksi (realization/construction); (4) tahap tes, evaluasi, dan revisi (test, evaluation, revision); dan (5) tahap implementasi (implementation). Penelitian ini hanya sampai pada tahapan tes, evaluasi dan revisi karena tahapan implementasi memerlukan proses dan waktu yang cukup lama.

\section{Tahap investigasi awal (prelimenary investigation)}


Fase investigasi awal dilakukan untuk menentukan masalah dasar yang diperlukan dalam pengembangan buku ajar teori graf untuk meningkatkan kemampuan representasi matematis mahasiswa. Pada fase ini dilakukan analisis kurikulum, analisis materi ajar dan analisis mahasiswa. Hasil analisis kurikulum menunjukkan kurikulum yang digunakan pada studi pendidikan matematika STKIP Soe yaitu kurikulum berbasis Kerangka Kualifikasi Nasional Indonesia (KKNI).Mata kuliah yang memuat materi teori graf adalah mata kuliah Matematika Diskrit dengan bobot 3 sks yang wajib diprogram mahasiswa di semester genap (semester IV). Dua dari tujuh Capaian Pembelajaran Mata Kuliah (CP-MK) matematika diskrit berkaitan dengan teori graf yaitu:

1. Mahasiswa mampu menjelaskan tentang teori graf.

2. Mahasiswa mampu menjelaskan masalah lintasan terpendek, pewarnaan graf dan pohon serta menggunakannya dalam penyelesaian persoalan terkait.

Dari dua CP-MK tersebut kemudian dikembangkan kedalam tujuh Sub CP-MK yaitu:

1. Mahasiswa mampu menjelaskan tentang pengertian graf, jenis dan terminologi graf

2. Mahasiswa mampu menjelaskan dan melakukan representasi graf

3. Mahasiswa mampu menjelaskan pengertian, kegunaan dan istilah pada pohon

4. Mahasiswa mampu menjelaskan tentang graf planar

5. Mahasiswa mampu menjelaskan tentang Eulerian dan Hamiltonian

6. Mahasiswa mampu menjelaskan dan memecahkan masalah yang berhubungan dengan masalah lintasan terpendek

7. Mahasiswa mampu menjelaskan dan memecahkan masalah yang berhubungan dengan pewarnaan graf.

Selanjutnya sub CP-MK digunakan dalam analisis materi ajar pada buku teori graf yang akan dikembangkan. Materi ajar yang berisi konsep dan latihan soal kemudian didistribusikan ke dalam tujuh bab yaitu pengenalan graf, representasi graf, pohon, graf planar, graf euler dan hamilton, masalah lintasan terpendek dan pewarnaan graf serta aplikasinya. Hasil analisis mahasiswa juga menunjukkan bahwa kemampuan representasi matematis mahasiswa program studi pendidikan matematika STKIP Soe Tahun akademik 2018/2019khususnya dalam representasi permasalahan yang berkaitan dengan graf masih rendah. Salah satu faktornya adalah kurangnya latihan soal dan juga sumber belajar yang ada hanya berupa $e$-book berbahasa inggris maupun power point dari dosen saja. Pada umumnya semua mahasiswa memiliki karakteristik belajar yang berbeda-beda dan juga memiliki keinginan belajar yang baik. Daya serap mahasiswa terhadap materi dalam pembelajaran juga cukup baik.

\section{Tahap desain(design)}

Tahap selanjutnya adalah tahap desain dimana hasil analisis kurikulum, materi ajar dan mahasiswa digunakan sebagai dasar dalam membuat desain buku ajar teori graf untuk meningkatkan kemampuan representasi matematis mahasiswa. Komponen buku ajar teori graf yang didesain bertujuan untuk mengembangkan representasi visual, verbal dan simbolik mahasiswa. Komponen buku ajar teori graf terdiri dari: cover depan, kata pengantar, daftar isi, daftar tabel, daftar gambar, materi per bab, referensidan cover belakang. Pada sajian materi setiap babnya dimulai dari pemaparan CP-MK, Sub CP-MK kemudian sub bab materi berupa defenisi, teorema, contoh soal dan latihan soal. Setiap defenisi dan teorema disertai dengan contoh dan penyelesaiannya serta jumlah soal latihan mencakup semua materi dalam bab.

\section{Tahap realisasi/konstruksi (realization/construction)}

Tahap ini merupakan tindak lanjut dari tahapan desain. Buku ajar teori graf disusun sesuai desain yang ada dan menghasilkan draf 1. Untuk tampilan model graf, tabel dan matriks dalam setiap bab disajikan dengan jelas dan lengkap untuk memfasilitasi pengembangan kemampuan representasi visual mahasiswa dalam menggunakan maupun membuat diagram, tabel atau grafik dalam menyelesaikan masalah. Contoh soal pada setiap bab juga disajikan untuk setiap konsep beserta tahapan penyelesaian yang lengkap untuk mengembangkan kemampuan representasi verbal mahasiswa dalam menuliskan langkah-langkah penyelesaian masalah, menyimpulkan atau menjawab soal menggunakan kata-kata. Dalam materipun, istilah dan notasi yang digunakan juga dibuat konsisten dalam setiap bab agar menghindari makna yang ambigu. Contoh soal dan penyelesaian 
latihan soal memfasilitasi mahasiswa dalam representasi simbolik yaitu membuat model matematis dari masalah yang diberikan dan menyelesaikannya dengan melibatkan ekspresi matematis.

\section{Tahap tes, evaluasi, dan revisi (test, evaluation, revision)}

Draf 1 hasil tahapan realisasi kemudian divalidasi dan diujicobakan pada tahapan ini. Validasi buku ajar dilakukan oleh tim ahli yang terdiri dari 2 dosen yang sudah berpengalaman dalam mengajar matematika diskrit terkhususnya teori graf. Komentar yang diperoleh adalah ada beberapa kesalahan pengetikan maupun ada beberapa penggunaan istilah yang belum konsisten. Semua komentar telah digunakan dalam revisi buku ajar.Hasil validasi buku ajar oleh dua validator seperti pada Tabel 1.

Tabel 1. Hasil Validasi Buku Ajar

\begin{tabular}{ccc}
\hline No & Validator & Presentase Penilaian \% \\
\hline 1 & Validator 1 & 90,77 \\
2 & Validator 2 & 86,15 \\
& Rata-rata & 88,46 \\
\hline
\end{tabular}

Hasil validasi pada Tabel 1 menunjukkan bahwa buku ajar yang dikembangkan valid pada kategori sangat valid karena berada pada rentang $86 \% \leq P_{v} \leq 100 \%$ sehingga buku tersebut layak untuk digunakan.Buku ajar teori graf yang telah dinyatakan valid kemudian diuji coba untuk melihat kepraktisan dan keefektifannya. Uji coba ini mengikuti modelquasi eksperimenyangdidesain dalam bentuk nonequivalent control group design. Uji cobamelibatkan dua kelas sampel, yaitu kelas eksperimen (diajarkan menggunakan buku ajar teori graf) dan kelas kontrol (tidak diajarkan menggunakan buku tersebut).Hasil tes kemampuan representasi matematis mahasiswa disajikan pada Tabel 2.

Tabel 2. Hasil Tes Kemampuan Representasi Matematis Mahasiswa

\begin{tabular}{ccccc}
\hline Statistik & \multicolumn{2}{c}{ Kelas Kontrol $(\mathrm{n}=23)$} & \multicolumn{2}{c}{ Kelas Ekperimen $(\mathrm{n}=20)$} \\
& Pre-test & Post-test & Pre-test & Post-test \\
\hline Nilai Tertinggi & 71 & 79 & 73 & 97 \\
Nilai Terendah & 39 & 45 & 38 & 52 \\
Rata-rata & 56,00 & 69,48 & 56,00 & 84,00 \\
Simpangan Baku & 9,69 & 9,41 & 8,93 & 9,48 \\
\hline
\end{tabular}

Tabel 2 menunjukkan bahwa kelas eksperimen dan kelas kontrol mengalami peningkatan kemampuanrepresentasi matematis dengan hasil perolehan skor pre-test lebih rendah dari skor posttest.Nilai rata-rata post-test pada kelas eksperimen lebih besar dari rata-rata post-test kelas kontrol yang menunjukkan kemampuan representasi matematis mahasiswa kelas eksperimen lebih baik dari kelas kontrol.

Analisis lanjutan keefektifan buku ajar teori graf terhadap peningkatan kemampuan representasi matematis mahasiswa dilakukan menggunakan uji $t$ sampel independen.Hasil uji prasyarat yaitu uji normalitas menunjukkan bahwa sampel berasal dari populasi yang berdistribusi normal dan uji homogenitas menunjukkan bahwa kedua sampel penelitian berasal dari populasi yang homogen. Berdasarkan hasil uji $t$ sampel independen dengan $\alpha=0,05$ diperoleh $t_{\text {hitung }}=5,030>t_{\text {tabel }}=1,684$ dengan derajat kebebasan= 41 yang berarti bahwa rataan kemampuan representasi matematis mahasiswayang diajarkan menggunakan buku ajar teori graf lebih baik dari kelas yang tidak diajarkan menggunakan buku ajar tersebut. Analisis skor gain normalisasi juga menunjukkan peningkatan kemampuan representasi matematis mahasiswa kelas eksperimen berada pada kategori sedang dengan rata-rata skor gain 0,65. Hasil ini menunjukkan bahwa buku ajar yang dikembangkan dapat membantu mahasiswa untuk memahami konsep teori graf dan merepresentasikannya dalam pembelajaran khususnya dalam permasalahan penjadwalan. Hal ini sejalan dengan hasil penelitian Ramziah (2016), Annajmi dan Afri (2019) dan Puspandari, Praja dan Muhtarulloh (2019) yang menyimpulkan bahwa pengembangan bahan ajar dapat meningkatkan kemampuan representasi matematis.

Uji kepraktisan buku ajar yang dikembangkan dilakukan melalui angket respon mahasiswa sebanyak 20 orang dan respon dosen sebanyak 2 orang.Hasil analisis angket diringkas pada Tabel 3. 
Tabel 3. Hasil Angket Respon terhadap Buku Ajar

\begin{tabular}{ccc}
\hline No & Responden & Persentasi Penilaian $(\%)$ \\
\hline 1 & Mahasiswa & 91,25 \\
2 & Dosen & 81,25 \\
& Rata-rata & 86,25 \\
\hline
\end{tabular}

Kepraktisan buku ajar yang dikembangkan diketahui dengan memberikan angket kepada mahasiswa dan dosen. Berdasarkan Tabel 3, diperoleh rata-rata persentaserespon mahasiswa dan dosen sebesar $86,25 \%$ yang menunjukkan bahwa buku ajar teori graf praktis untuk digunakan dalam pembelajaran mata kuliah matematika diskrit bagi mahasiswa pendidikan matematika STKIP Soe. Hal ini disebabkan karena pembelajaran dengan buku ajar teori graf mendorong kemandirian belajar mahasiswa karena penggunaan buku ajar teori graf memfasilitasi mahasiswa dalam tahapan merencanakan, monitoring dan evaluasi belajar dirinya. Mahasiswa tidak lagi kesulitan mendapatkan sumber bacaan untuk materi teori graf dalam bahasa indonesia karena semuanya telah tersaji secara terurut menggunakan istilah maupun notasi yang mudah dipahami.Gambar-gambar yang ditampilkan dalam buku ajar juga jelas sehingga mendukung mahasiswa dalam melakukan representasi graf yang tepat.Penggunaan buku ajar teori graf juga memotivasi mahasiswa untuk menyelesaikan soal-soal yang diperoleh setelah membaca materi dan menyelesaikan contoh soal.Hal ini sesuai dengan penelitian Theis dan Junita (2019) yang menyatakan bahwa setelah membaca bahan ajar analisis real yang dikembangkan mahasiswa akan menghubungan teorema sebelumnya dan memperhatikan contoh-contoh yang diberikan. Selain itu, mahasiswa akan menyelesaikan beberapa masalah pada latihan-latihan yang diberikan.

\section{SIMPULAN}

Berdasarkan hasil dan pembahasan dapat disimpulkan bahwabuku ajar teori graf valid dan layak digunakan dalam pembelajaran serta praktis dan efektif untuk meningkatkan kemampuan representasi matematis mahasiswa.

\section{DAFTAR PUSTAKA}

Abdullah, I. H. 2012.Pengembangan Bahan Ajar untuk Meningkatkan Kemampuan Pemahaman dan Representasi Matematik Siswa melalui Pembelajaran Kontekstual yang Terintegrasi dengan Soft Skill.Delta-Pi: Jurnal Matematika dan Pendidikan Matematika,1(2):65-74.

Amin, dkk.2016. Perbedaan Prestasi Belajar Matematika Siswa ditinjau dari Gaya Belajar dan Model Pembelajaran. Jurnal Prima Edukasia, 4(1):12-19.

Annajmi, A. dan Afri, L. E. 2019.Pengaruh Penggunaan Lembar Aktivitas Siswa Berbasis Metode Penemuan Terbimbing Terhadap Peningkatan Kemampuan Representasi Matematis Siswa. Mosharafa, 8(1):95-106.

Fitria, M., Arnawa, M., Lufri. 2014. Pengembangan Modul Aljabar Linear Elementer bernuansa Konstruktivisme berbantuan ICT. Jurnal Eksakta, 1: 34-42.

Mudlofir, A. 2011.Aplikasi Pengembangan Kurikulum Tingkat Satuan Pendidikan dan Bahan Ajar. Jakarta: Raja Grafindo Persada.

National Council of Teachers of Mathematics.2000. Principles and Standards for School Mathematics. Restorn, VA: NCTM.

Permendiknas nomor 22 tahun 2006 tentang Standar Isi Pendidikan Dasar dan Menengah.

Puspandari, I., Praja, E. S. dan Muhtarulloh, F. 2019. Pengembangan Bahan Ajar dengan Pendekatan Induktif untuk Meningkatkan Kemampuan Representasi Matematis Siswa SMP.Mosharafa, 8(2):307-318.

Ramziah, S. 2016. Peningkatan Kemampuan Representasi Matematis Siswa kelas X2 SMAN 1 Gedung Meneng Menggunakan bahan Ajar Matriks Berbasis Pendekatan Saintifik. Mosharafa, 5(2):138-147. 
Sabirin, M. 2014. Representasi dalam Pembelajaran Matematika. JPM IAIN Antasari, 1(2): 33-44.

Sabri, H. A. 2007. Strategi Belajar Mengajar dan Micro Teaching.Ciputat :Quantum Teaching.

Sinaga, dkk.2016. Kemampuan Representasi Matematis Siswa ditinjau dari Gaya Belajar pada Materi Fungsi Kuadrat di SMA.Jurnal Pendidikan dan Pembelajaran, 5(6): 1-12.

Syafri.2017. Kemampuan Representasi Matematis dan Kemampuan Pembuktian Matematika.Jurnal Edumath, 3(1): 49-55.

Theis, R. dan Junita, R. 2019. Pengembangan Bahan Ajar Analisis Real Untuk Memfasilitasi Self Regulated Learning Mahasiswa. Edumatica, 9(1):61:74. 